This PDF is a selection from a published volume from the National Bureau of Economic Research

Volume Title: Economic Regulation and Its Reform: What Have We Learned?

Volume Author/Editor: Nancy L. Rose, editor

Volume Publisher: University of Chicago Press

Volume ISBN: 0-226-13802-X (cloth); 978-0-226-13802-2 (cloth);

978-0-226-13816-9 (EISBN)

Volume URL: http://www.nber.org/books/rose05-1

Conference Date: September 9-10, 2005

Publication Date: June 2014

Chapter Title: Antitrust and Regulation

Chapter Author(s): Dennis W. Carlton, Randal C. Picker

Chapter URL: http://www.nber.org/chapters/c12565

Chapter pages in book: (p. 25 - 61) 


\title{
Antitrust and Regulation
}

\author{
Dennis W. Carlton and Randal C. Picker
}

Within a brief span of time, Congress adopted the Interstate Commerce Act (1887) and the Sherman Act (1890). In imposing federal regulation on railroads, the Interstate Commerce Act inaugurated the era of substantial federal regulation of individual industries, while the Sherman Act created a baseline for the control of competition in the United States by generally barring contracts in restraint of trade and forbidding monopolization. The rise of the railroads and the great trusts raised concerns about economic power and spurred politicians to formulate a national policy toward competition. Since 1890, policymakers have been forced repeatedly to work through how to interleave a fully general approach to competition under the antitrust laws with industry-specific approaches to competition under regulatory statutes.

This has been a learning process, but even without learning, shifting political winds would naturally lead to fits and starts as antitrust and specific regulatory statutes have jostled and combined and sometimes even competed in establishing a framework for controlling competition. After more

Dennis W. Carlton is the David McDaniel Keller Professor of Economics at the University of Chicago Booth School of Business and a research associate of the National Bureau of Economic Research. Randal C. Picker is the James Parker Hall Distinguished Service Professor of Law at the University of Chicago Law School and a senior fellow at the Computation Institute of the University of Chicago and Argonne National Laboratory.

Randal C. Picker thanks the Paul Leffmann Fund, the Russell J. Parsons Faculty Research Fund, and the John M. Olin Program in Law and Economics at the University of Chicago Law School for their generous research support, and through the Olin Program, Microsoft Corporation and Verizon. We thank Andrew Brinkman for research assistance and Thomas Barnett, Timothy Bresnahan, Richard Epstein, Jacob Gersen, Al Klevorick, Lynette Neumann, Gregory Pelnar, Sam Peltzman, Richard Posner, Nancy Rose, and the participants of the NBER conference on regulation for their helpful comments. For acknowledgments, sources of research support, and disclosure of the authors' material financial relationships, if any, please see http://www.nber.org/chapters/c12565.ack. 
than a century of effort, it is possible to advance a few general conclusions. Antitrust can say no, but struggles with saying yes. Less cryptically, antitrust is a poor framework for price setting or for establishing affirmative duties toward rivals. Price setting in a nonmarket context often requires detailed industry knowledge and often turns on political decisions about levels of service and the rate of return to capital needed to provide those services. The virtue and vice of federal judges is they are generalists, not industry specialists, and, once appointed, they are insulated from the political process. If there is a natural monopoly and prices need to be set or we are going to create a duty to, say, share an incumbent's phone network with an entrant, the evidence suggests that it is generally best to do that, if at all, through (enlightened) regulation, not antitrust, though obviously poor regulation can impose enormous costs.

However, antitrust says no very well, while regulators often have a hard time saying no. Area-specific regulation through special agencies gives rise to the fear that the regulators will be captured by the regulated industry (or other interest groups). Regulators will have come from industry or will dream of exiting to private sector salaries. Regulators will not say no often enough to proposals that benefit special interests. But federal judges are genuinely independent (or, at least, more so than regulators) and the docket of the federal judiciary is completely general. A general antitrust statute, implemented by independent federal judges - limited to issues within their competence - can protect the competitive process, especially with the rise of economic reasoning in antitrust.

Our main conclusion is that in the century-long seesaw battle over how to design competition policy, the Sherman Act has turned out to be more enduring than regulation. As the difficulties of regulation have emerged and as economic reasoning has improved the effectiveness of the Sherman Act, enforcement of the Sherman Act through an independent judiciary has shown itself to deliver lower prices and less promotion of special interests than regulation, causing a shift away from regulation. This does not, of course, mean that all regulation should vanish, especially for industries with natural monopoly characteristics, but rather that, when necessary, regulation should try to allow as much competition as possible, constrained only by antitrust law. Where activities in an industry remain partially regulated, antitrust and regulation can be used together in a complementary way to control competition and, in some cases, it is possible to use antitrust as a constraint on regulators.

This chapter is divided into three sections. First, we consider the general question of how competition policy should be implemented. We do this by considering possible roles for courts and regulatory agencies as set out in the modern political science literature on legislative bargaining. We analyze the relative advantages and disadvantages of regulation versus antitrust as a means of formulating competition policy. Industries will frequently seek to 
establish a sharp boundary between the industry and antitrust by obtaining a legislative antitrust immunity for the industry. Being outside of antitrust means that the industry members can act without fear of antitrust liability. But the industry might want more; it might want a federal regulator's help in enforcing cartel deals or in blocking entry by potential competitors. In those cases, industries may want more than mere exclusion from antitrust; they will want affirmative industry regulation and a regulator with enforcement power.

Second, we return to the beginning of the formulation of competition policy by considering the period starting with the Interstate Commerce Act and the Sherman Act. This history illustrates the initial view of regulation and antitrust as two competing alternatives to control competition, but with some recognition that the two would interact in unforeseen ways. We pursue the central question that dominated early competition policy and remains a central policy question, namely, how should prices be set?

Third, we turn our attention to a group of industries that have been a focus of regulation for over one hundred years - network industries - and analyze their recent development. In many of these industries - particularly the transportation industries, such as airlines, trucking, and railroads - we have moved powerfully away from regulation and have largely deregulated those industries. Deregulation effectively shifts relative authority for regulating competition away from industry regulators and, absent a legislative antitrust immunity, toward general antitrust enforcement. In these industries, deregulation has lifted artificial barriers to integration, and we have seen these industries respond by moving toward greater vertical integration, thereby eliminating interconnection and other dealings difficulties and possible double marginalization. In the network industries that remain heavily regulated - for example, electricity and telecommunications - we address the fundamental question that has occupied and continues to occupy regulatory and antitrust decisions in those industries: how should those markets be structured and specifically what sort of mandatory access rights should be established? We use this recent history to illustrate the movement away from regulation toward antitrust, with the two being used as complements to control competition in some industries.

\subsection{Assigning Responsibility for Controlling Competition}

We begin by framing the general problem faced by Congress and the president in choosing whether and to what extent to delegate implementation of a policy to a third party. The delegation will take the form of legislation and the scope of the delegation may be determined in part by the specificity of the language used in the statute. We want to address that problem generally and then turn to what that means for the interaction of antitrust and regulation. 


\subsubsection{The General Setting}

Under the US Constitution, laws are enacted when the Senate, the House, and the president each vote in favor of a proposed bill. This is a simplified statement in that it ignores the possibility that Congress has sufficient votes (two-thirds in each chamber) to override a veto by the president. It also skips over the interesting and tricky issue of the extent to which domestic legislation can be set through the treaty-making power, where the president is empowered to make treaties, provided that two-thirds of the Senate vote in favor.

Following McCubbins, Noll, and Weingast (1989), we treat the process of creating legislation as a principal/agent problem or, more precisely and more interestingly, as a three principal/multiple agents problem. It is conventional (see, e.g., Shepsle and Bonchek 1997, 358-68) in the rational choice literature in political science to model legislation as a principal delegating power to an agent, where either a court or an agency acts as the agent in implementing the legislation. In the principal/agent problem faced in creating legislation, Congress and the president typically delegate to one of two agents: Article III courts or specialized agencies subject to court oversight. By institutional design, Congress and the president have relatively weak controls against the judiciary - we call this separation of powers - but, together and separately, the House, Senate, and president can choose to retain stronger control over agencies.

Focus on a standard principal/agent problem; namely, that the agent will depart from the principal's goals and pursue his own. In the political science literature, this is labeled as the problem of bureaucratic drift. For legislation to get passed, the House, Senate, and president negotiate over potential policies. But delegation is inevitable: judges decide actual cases, not Congress or the president, and with the rise of the administrative state, implementation of legislation can be delegated directly to courts or first to agencies with appeals to courts (and judicial review of agency action need not be a given).

The negotiation process that results in unanimous agreement by the House, Senate, and president on new legislation has to take into account what will happen in the subsequent delegation to courts or agencies. Each player in the negotiation game should do backwards induction looking forward to see how the agent will actually implement the enacted legislation, and in light of that, design the legislation. (The players could just care about enactment and not about implementation if that is how their constituencies keep score, but we will assume that all participants are interested in actual results, and not just appearances.) To match the political science literature, treat the House $(\mathrm{H})$, Senate $(\mathrm{S})$, president $(\mathrm{P})$, and agent as each having preferences over the particular policy in question and focus on the essential dynamic that takes place among our four players. After negotia- 
tion, unanimity is reached and a bill is passed (absent unanimity nothing happens). The agent now implements the legislation.

What constrains how the agent does so? Consider possible sources of restrictions: the original legislation, oversight and monitoring, internal agency norms, and the threat of subsequent legislation. Focus initially on the possibility of constraint through subsequent legislation that overturns the decision of the agent. Note that this legislation requires a unanimous vote among $\mathrm{H}, \mathrm{S}$, and $\mathrm{P}$, as any one of them has the power to block a change from the new status quo defined by the agent's decision. As an initial cut, the agent then has a free hand to implement her policy preferences rather than implement with fidelity the deal struck among H, S, and P. So if the agent's policy preferences matched $\mathrm{P}$ more closely, the agent could implement a policy that $\mathrm{P}$ would find superior to the deal captured in the negotiated legislation, and $\mathrm{P}$ would veto any subsequent legislative effort to overturn the agent's decision.

This does not mean that the new status quo would remain, but any new law negotiated among $\mathrm{H}, \mathrm{S}$, and $\mathrm{P}$ would need to make $\mathrm{P}$ better off than he is under the agent's decision. And in the face of that law, the agent could once again refuse to implement the deal negotiated and instead implement her policy preferences. Of course, none of this should be lost on $\mathrm{H}, \mathrm{S}$, and $\mathrm{P}$ when they negotiate the original law. Again, they will care about how the legislation is actually implemented, not the deal cut. H, S, and P can anticipate bureaucratic drift. If $\mathrm{H}$ and $\mathrm{S}$ know that the agent will deviate from the original statute in the direction of $\mathrm{P}$ with the agent's action protected by P's veto, $H$ and $S$ will never make the deal in the first place. A little bit of backwards induction goes a long way.

We quickly see the complexities of having a process involving delegation. The agent can try to implement his own agenda, deviating from the original intent, but not enough to induce intervention by the principals. Moreover, if $\mathrm{H}$ has been delegated control over the agent, $\mathrm{H}$ can cheat on the agreement with HSP and deviate from the original agreement. If a congressman wants to try to cheat on the original legislative deal, he can do so if he can exert power over his agent. As Landes and Posner (1979) argued in their explanation of the role of an independent judiciary, the congressman can commit to not cheating by relinquishing his power over the agent. At the same time, giving up control over the agent means that the agent now has freedom to implement her own policy preferences. If someone's hands are tied at the front end, it equals loss of control at the back end. If the agent does not face meaningful discipline, why should the agent pay much (any?) attention to the statute at all?

But at the same time, independence means that the agent can implement her preferences in the veto zone; that is, the spots in the policy space where Congress and the president will not agree unanimously to overturn the agent's decision. And the fact will be anticipated by the institutional players 
who will be disadvantaged by the deviation. They will not want independence in their agent and will instead want to design controls over the agent that make fidelity to the original deal possible.

This would be true if $\mathrm{H}, \mathrm{S}$, and $\mathrm{P}$ were just seeking to implement their own independent policy preferences, but it would also be true if we think of the lawmakers as just selling off legislation to the highest bidder (or as having preferences that value both legislative outcomes and transfers from legislation buyers). $\mathrm{H}, \mathrm{S}$, and $\mathrm{P}$ will also want controls on themselves, at least as a group, so that they can ensure that their control over the agent does not allow them to cheat on the original deal that was cut amongst themselves or with the legislation purchaser. After the fact, they would like to cheat, either individually or as a group, but that too will be anticipated by the legislation purchaser, so $\mathrm{H}, \mathrm{S}$, and $\mathrm{P}$ need a commitment mechanism to maximize the amount that they can charge legislation purchasers.

We can sketch out what such a system might look like. Consider a basic public choice model with an interested party simply purchasing legislation that will be implemented by an agent. We can offer $\mathrm{H}, \mathrm{S}$, and $\mathrm{P}$ each some levers of oversight over the agent. That may be enough to solve the problem of the agent cheating. H needs to have sufficient individual power to block moves by the agent away from the original law, and so too for $\mathrm{S}$ and P. Or we need to make sure that the legislation purchaser can exercise oversight powers against $\mathrm{H}, \mathrm{S}$, and $\mathrm{P}$ to make sure that they faithfully implement the original deal bought and paid for by the legislation purchaser.

What should our legislation purchaser fear more, cheating by the principal or cheating by the agent? Purchasers have little control over Article III judges and much more control over congressional principals and agency agents. Both of these should push the legislation purchaser toward favoring a captive agency. Legislation purchasers are well situated to punish a member of Congress who cheats on the original deal by imposing her will on the agency. Members of Congress run every two years (House) or six years (Senate) and are constantly raising money for reelection (the best way to discourage competing candidates is to amass a large pile of money). A member who cheats on a deal with a legislation purchaser reveals himself to be a poor candidate for future deals and future campaign contributions. The need to return to the market for campaign funds disciplines members of Congress from using their influence on agents to cheat on the original deal that was cut. In contrast, legislation buyers can exercise little indirect or direct control over judges, since Congress and the president both lack control over Article III judges.

We should make one other point about this structure. Agency decisions are typically subject to appeals to independent federal judges. This would seem to make the judges the ultimate authority, but that largely depends upon what judges do with agency actions. Under the Supreme Court's Chevron doctrine (Chevron, Inc. v. Natural Resources Defense Council, 467 U.S. 
$837,1984)$, judges give agencies wide latitude in interpreting federal statutes. Not unlimited latitude, but Chevron is a policy of substantial deference to agencies. Chevron deference creates an agent largely outside of judicial control, and therefore subject to meaningful congressional control. This in turn means that Congress and the president can more credibly commit to those seeking legislation by delegating to independent agencies than it can to Article III courts. Chevron preserves broad independence for agencies as against the courts - thereby making them into actors that elected officials can control — while appeals to courts operate as a hedge against agents who have deviated too far from what their principals wanted.

\subsubsection{Agent Choice in Antitrust and Regulated Industries}

On July 2, 1890, Congress passed the Sherman Act and in so doing created a baseline for the control of competition in the United States. To the modern eye, the Sherman Act is notable for its simultaneous brevity and comprehensiveness. The entire statute is set forth in eight sections and barely covers more than one page in the Statutes at Large. Section 1 condemned every contract in restraint of trade and Section 2 made a criminal of every person who monopolized.

\section{The Sherman Act: Court or Agency?}

Why was the Sherman Act implemented in the federal courts and not through a federal agency? Consider a little history. At the time that the Sherman Act was passed, the Interstate Commerce Commission was still a baby, a bold experiment in a highly specialized but central industry. It would have been a sizable leap of faith to apply the same mechanism to the entire economy. The natural, conservative move was to use the federal courts. Moreover, to fast-forward twenty-five years to 1914, we did take a step in that direction when we created the Federal Trade Commission (more on that at the end of section 1.2).

The agency choice literature (Fiorina 1982; Stephenson 2005) compares the relative stability of decision making in agencies and courts. Commissions typically are small and are controlled by the party of the president; the president also chooses the chair of the commission (this was roughly how the ICC worked and is how the FCC and FTC work today). Turnover of the presidency means turnover of the commission. Commissions therefore may exhibit high variance across periods of time - a Democratic FTC looks different from a Republican FTC — but greater coherence among related decisions made within a particular window. By contrast, the federal courts are quite stable over time, but are subject to very little control at any point in time. But the sheer number of judges means that two contemporaneous decisions may reach quite different outcomes.

This helps to explain why in 1887 an agency was a relatively more attractive choice for railroads than it was for the general economy. The railroads 
were the first great network industry (we could fight about canals). The nature of a network is that regulatory decisions in one part of the network can have large effects in other parts of the network. That is true whether the inconsistent decisions are about technical matters or about rate decisions and what those decisions mean for the recovery of fixed costs. So if one regulator sets a track gauge of 5 feet, while another sets it at 4 feet, 6 inches, the network will operate inefficiently given the inconsistent technical standards.

In a similar fashion, inconsistent rate structures across parts of a network can make it quite difficult to recover fixed costs. In the early days of railroad regulation, state regulators were setting low rates for intrastate shipments, hoping to keep the railroads solvent on the back of interstate rates. The Supreme Court understood that fully when it decided Smyth v. Ames in 1898 (169 U.S. 466, 1898). In Smyth, the Court addressed the scope of constitutional protection for rate setting for railroads and limited state rate making that the Court concluded could be confiscatory. The same tracks would be used for intrastate and interstate shipments, and giving state rate setters free reign for intrastate state rates would force up interstate rates or push the railroads toward insolvency. For network industries, piecemeal regulation can create expensive and even insurmountable inconsistencies.

But outside of railroads, in the rest of the economy around the beginning of the twentieth century, regional inconsistencies in industry practices were less important. If the Second Circuit reached one antitrust outcome and the Seventh Circuit another, the greater the extent to which economic activity was local or regional, the less that these regulatory differences mattered. Local (uncoordinated) antitrust enforcement, whether federally at the circuit level or by states, was less costly to the economy when the economy was more of a local economy than it is today.

When many parts in the economic system need to move at the same time-when we are speaking of coevolution, as it were, rather than just evolution - it may be very hard for lower federal courts to coordinate decision making, and Supreme Court decisions are rare and slow to come. The inefficiency in a network industry of having uncoordinated decision making could be very high. Plus courts are passive when it comes to agenda setting: they can only decide the cases that come before them. In contrast, agencies expressly control their own agendas, subject to the original statute to be sure, but tied down often by nothing more than a public interest standard. The ability to set agendas means that agencies can push forward on all parts of the economic system at the same time. Agencies can change a number of policies simultaneously and can do so sharply - moving from the existing framework to a substantially different spot in a process of punctuated equilibria - while courts have little control over agendas, can only decide the issues directly before them, and are normally limited to smaller moves consistent with judicial precedent. Our logic predicts that as policy concerns with competition arise in particular industries, all else being equal, network 
industries are more likely than nonnetwork industries to see their competition regulated by agencies, rather than the courts.

\section{Boundary Definition in Regulation and Antitrust}

After the ICC and Sherman Act were established, how did the evolution of competition policy in particular industries proceed? What guided assignments of tasks between regulation and antitrust? Every attempt to control competition after 1890 - whether within antitrust proper or outside of antitrust in the form of area-specific regulation - must be understood in the context of the Sherman Act. Given its breadth, we might ask why weren't the antitrust laws sufficient to regulate all industries? The prevailing - but, to be sure, not universally held - view of antitrust law in the United States is that it is designed to promote efficiency by protecting the competitive process to benefit society. Why shouldn't that be enough?

Boundary definition should turn on the comparative advantages of regulation and antitrust. To grossly simplify, while both antitrust and regulation are a mix of economics and politics, antitrust is now organized around an economic core, while regulation is frequently shaped by the political process. To prolong this, while the decision by the Antitrust Division in the Department of Justice or by the Federal Trade Commission to bring a case may be influenced by politics, once a case is brought, the ultimate decision regarding the case is made by a federal judge.

If we believe that the agent making a decision should reflect public welfare, agencies (and the regulation that comes with them) are a superior tool to broad antitrust statutes implemented by federal judges. Judges have no particular ability or accountability in establishing quality standards of the sort that will inevitably be required in, for example, the electricity industry or telecommunications. Pricing in electricity, for example, will depend on our willingness to endure blackouts, and if we think that at least parts of the electricity system are a natural monopoly - the transmission grid itself - the government will almost certainly be involved in price setting. Judges have little if any ability to determine the public's tolerance for blackouts and we should want that to be determined as part of a political process. And we should expect that price setting here will require the consideration of huge amounts of specialized data. All of that suggests industry-specific regulation and accountable regulators, and not general rules for competition implemented by judges separated from overall social preferences.

At the same time, we need to recognize that regulatory carve-outs from antitrust can create risks to competition. These carve-outs define sharp boundaries between antitrust and regulation. Industries will often display two natural patterns in defining the boundaries between antitrust and regulation: antitrust immunity or affirmative regulation coupled with agency enforcement power, especially enforcement power directed at implementing industry agreements on prices or at blocking new entrants. One sharp 
boundary is a legislative antitrust immunity for a particular industry. The immunity effectively empowers the industry to implement voluntary agreements among the industry members. The immunity replaces antitrust control through courts not with a separate agency and new industry-specific regulation but instead with self-regulation by the industry. A naked antitrust immunity means no government competition regulation at all.

But an industry might want more. The antitrust immunity itself does not give the industry a means of enforcing deals within the industry nor does it offer a means of blocking new entry into the industry. It is one thing to have an industry cartel that is free of the fear of federal antitrust enforcement; it is quite another to have a cartel that is enforced either by federal legislation or by a federal regulator so as to allow the cartel to be more effective and one that ensures that no new competitors will emerge to boot. Cartel members have powerful incentives to cheat on the cartel and we expect cheating to put natural pressure on the sustainability of an anticompetitive agreement. But if federal regulation itself will help to sustain a cartel, then we should expect the industry to seek not just an antitrust immunity - a guarantee of no federal antitrust enforcement actions against the cartel-but instead to seek legislation or a federal regulator to guarantee the enforcement of the cartel agreement and to further limit possible competition by excluding entry.

We therefore expect that where an interest group is powerful but cannot control entry on its own it will combine an antitrust exemption with legislation that restricts entry, either directly in the statute, or in the face of uncertainty about the ways to preserve the cartel or about the ability to obtain future legislation, through an agency regulator. Failing that, the industry may prefer regulation to competition, with the regulator controlling entry and perhaps price. But as we know from the theory of political regulation, there are many interest groups that will have a voice in the regulatory process. Different groups of consumers and firms will have their own interests and compromises amongst them will be up to the regulator. It is unusual for a regulator to favor one group to the exclusion of all others, as Peltzman (1976) especially has shown (see also Stigler 1971; Posner 1974; and Becker 1983). Therefore, a very powerful interest group with clear goals on how to achieve cartelization would likely have a preference to obtain exemption with legislative entry restrictions rather than rely on regulation.

\subsubsection{Antitrust Immunities}

An unregulated industry subject only to the antitrust laws might seek an exemption from these laws for one of two reasons. The industry might want to avoid inefficiencies that the antitrust laws create. Alternatively, the industry might want to avoid the constraints of the antitrust laws and want to engage in anticompetitive behavior such as cartelization. Policing that line - separating good antitrust immunities from the bad — can be tricky.

In some circumstances, collective action might be required to achieve 
efficiency, but Section 1 flatly forbids any contract in restraint of trade. Many R\&D and information gathering activities, as well as sports leagues organized as joint ventures, create a high risk of antitrust liability, as the history of antitrust cases demonstrates. ${ }^{1}$ Farmer cooperatives are another example of how small firms may be able to achieve some economies by collective action but still remain independent firms that compete against each other. Often, these collaborative activities created no market power and only efficiencies but these could have faced Sherman Act actions, especially in the early days of antitrust. Indeed Bittlingmayer (1985) has argued that the Sherman Act created antitrust liability for cooperative activities among horizontal competitors and thereby encouraged the massive merger wave around 1900.

We may be able to solve this problem within antitrust proper through careful development of doctrine, but beneficial activity that is close to the antitrust line risks treble damages. Plus firms face individual liability if they end up on the wrong side of the line, while an improvement in antitrust doctrine benefits the industry as a whole. This mismatch between private costs and industry benefits means that for a particular industry, exemption from antitrust might be easier to implement than internal reform of antitrust doctrine through the courts.

Antitrust immunities also serve a channeling function for activities to influence competition policy. Absent the immunity, activity that influences competition policy takes place in the courts, before the Federal Trade Commission, and in Congress through the pursuit of new legislation. Immunity channels this competition, mainly to Congress. We can think of antitrust immunity as a commitment about how the policy game will be played, a commitment about where the next move will be made. It means that courts and agencies do not get to move, and that instead the next move will be made by the legislature, though, of course, that could be a future legislature, rather than the current legislature.

There are many important parts of the economy that have received exemptions from the antitrust laws. The major areas are:

- Agriculture and Fishing. The exemption allows cooperatives to form and even have joint marketing. Section 6 of the Clayton Act (15 U.S.C. § 17) protected certain labor, agricultural, and horticultural organizations, and the 1922 Capper-Volstead Act (7 U.S.C. §§ 291-292) addressed joint marketing associations. Section 1 of the Sherman Act is odd in that it does not allow two firms, each with no market power, to set price, even though together they have no ability to raise price. The per se treatment of such price fixing is presumably justified by the belief that such price setting can have no procompetitive purpose. An antitrust exemption

1. See, for example, Maple Flooring Manufacturers Association v. United States, 268 U.S. 563 (1925); and Carlton, Frankel, and Landes (2004). 
for a particular industry allows this type of price-fixing to go forward without the fear of liability.

- $R \& D$ Joint Ventures. Similar to the case of agricultural cooperatives, the cooperation of rivals to achieve efficiencies in $R \& D$ can raise antitrust issues. Under the National Cooperative Research Act of 1984 (15 U.S.C. $\$ \S 4301-4306$ ) certain of those activities are exempt from challenge as per se illegal and antitrust's treble damage rule is called off.

- Sports Leagues. Sport leagues consist of competing teams that must cooperate in order to have a viable league. There have been numerous antitrust cases in sports because of the peculiar combination of competition and cooperation needed for a successful league. Today sports leagues often start as a separate single firm so as to avoid antitrust challenge. When Curt Flood sued baseball commissioner Bowie Kuhn to try to end baseball's reserve clause, the Supreme Court confirmed that the antitrust laws did not apply to baseball (though they apply to other sports) (Flood v. Kuhn, 407 U.S. 258, 1972). Congress later brought professional baseball's dealings with the players into antitrust, while leaving baseball's prior antitrust exemption otherwise in place (Curt Flood Act of 1998, Pub.L. 105-297). The Sports Broadcasting Act of 1961 (15 U.S.C. $\$ 1291$ ) allows leagues to act as one entity in negotiations with television without antitrust liability.

- Ocean Shipping. International cartels set rates for certain ocean shipping routes. Entry is not typically controlled, though on some routes entry is unlikely. The industry's antitrust exemption (46 U.S.C. § 40307) is sometimes defended (Pirrong 1992) on the grounds that the core does not exist and that, without the cartel, chaos would reign with frequent bankruptcies and unreliable service.

- Webb-Pomerene. Added in 1918, this act allows cartels to set the price for exports, presumably on the logic that the antitrust laws do not protect foreign consumers (15 U.S.C. $\$ 61)$.

- Colleges. In response to an antitrust suit alleging that the top colleges agreed on a financial aid formula to use to give out scholarship aid, Congress passed the Higher Education Amendments of 1992 (Pub.L. 102-235) to allow colleges to agree on a common formula for financial aid free of possible antitrust liability without allowing colleges to discuss aid for any particular applicant.

- Professional Societies. Many societies such as those involving doctors and lawyers have the ability to influence entry into their profession. Although Professional Engineers (435 U.S. 679, 1978) has limited the scope of the exemption, it is still the case, for example, that medical societies control the number of doctors by specialty and limit the number of medical schools that can receive accreditation. The professional societies are given this exemption because they are also regulating the quality of the profession. In a recent antitrust attack on parts of the 
medical profession, a group of residents brought an antitrust suit aimed at the medical schools, teaching hospitals, and professional societies for the medical residency system. In that system, doctors seeking advanced training are assigned one hospital to work at. There is limited competition for the resident. Legislation (Section 207 of the Pension Funding Equity Act of 2004 [Pub. L. 108-218]) was passed to declare that no antitrust liability results from the administration of the medical residency system, and the original lawsuit was dismissed (Robinson 2004).

- Labor. Unfavorable court decisions toward labor led eventually to the labor exemption. In 1908, the Supreme Court found a union liable under the antitrust laws for organizing a boycott of a particular firm's product (Lowe v. Lawlor, 208 U.S. 274, 1908). This decision caused labor to pressure Congress to declare in 1914 in the Clayton Act that labor organizations were exempt from the antitrust laws. A subsequent decision (Duplex Printing Company v. Deering, 254 U.S. 433, 1920) found that the unions could still be liable if they assisted other unions at another firm. This led to pressure to pass the Norris-La Guardia Act in 1932, which removed virtually all jurisdiction over labor from the federal courts (Benson, Greenhut, and Holcombe 1987). ${ }^{2}$ As if that were not enough, since then, the federal courts have added a nonstatutory labor exemption to further limit the scope of potential antitrust liability in labor situations (Brown v. Pro Football, Inc., 518 U.S. 231, 1996).

As a mechanism to establish an efficient competition policy, the use of immunities may be socially desirable in those instances where some collective action is needed for efficiency. Although some immunities may be described that way, others confer market power on the exempted industries to the detriment of society.

\subsection{Control over Rates: The Rise of Antitrust and the Regulation of Railroads}

We return to the early period of antitrust and regulation because it illustrates the interaction between explicit regulation and the Sherman Act. The Sherman Act was passed three years after the Commerce Act. The interaction between the two and the results of that interaction not only illustrate

2. This pattern of legislation and antitrust interacting — and specifically an antitrust case being a stimulus for either immunity or regulation - applies also to other industries that we do not discuss herein. For example, the Southeastern Underwriters case (322 U.S. 533, 1944) found that insurance companies had antitrust liability for rate agreements even in states that regulated rates. This discussion led to the passage of the McCarran-Ferguson Act, granting antitrust immunity where states regulated insurance. Similarly, Otter Tail(410 U.S. 366, 1973) found antitrust liability for an electric utility company for failure to interconnect with another utility even though the Federal Power Commission (FPC) could order such interconnection. The Court ruled that the FPC's powers were too limited. This decision led to legislation giving the Federal Energy Regulatory Commission (the renamed FPC) greater powers to force interconnection. 
the economic forces at work that we have discussed, but also have shaped the subsequent development of competition policy for the century. The history highlights the early view of regulation and antitrust as substitutes for each other with a recognition that the two might interact through unforeseen ways.

The Interstate Commerce Act was adopted on February 4, 1887. The new law addressed the operation of interstate railroads and limited rates to those that were "reasonable and just." The statute barred more general "unjust discrimination" and "undue or unreasonable preferences," and made unlawful long-haul/short-haul discrimination. The act also addressed directly competition among railroads by barring contracts among competing railroads for the pooling of freight traffic.

Pools dividing freight and profit had been common before the passage of the Commerce Act and indeed had been created openly in an effort to control competition among railroads (Grodinsky 1950). The structure of the railroad business prior to the Commerce Act created incentives to raise and stabilize rates through cartels and pools (Hilton 1966). The number of railroads competing on a particular route was usually small and fixed costs were high. The former meant that the costs of agreeing and monitoring that agreement were relatively low. The irreversibility of the investments in the track meant that competitors were locked into place and could not move elsewhere if the level of demand would not support multiple competitors. Absent cartels, the incentive to have rate wars was great.

We can think of the initial regulation of railroads as a search for an institutional structure that protected shippers from monopoly power and discrimination while making it possible for railroad investors to earn competitive rates of return. The Interstate Commerce Act limited competition among railroads, while also protecting local shippers against perceived discrimination in rates. (Whether this was a net plus or minus for the railroads is an issue we do not address here-for a discussion of this issue see Gilligan, Marshall, and Weingast 1989.) The Sherman Act was passed three years after the Commerce Act, without a clear indication of how the two acts should interact. We now turn to that interaction and its consequences.

\subsubsection{The Interaction of the Sherman Act with the Interstate Commerce Act: The Problem of Trans-Missouri}

The Sherman Act said nothing specific about railroads. Did the Sherman Act cover railroads, too, or should we think that the more specific, if somewhat earlier, provisions of the Interstate Commerce Act controlled railroads? These questions were posed to the courts in January of 1892, when the United States brought an action to dissolve the Trans-Missouri Freight Association. The Trans-Missouri Association had been formed in March of 1889 as a joint rate setting organization. While Section 5 of the Interstate Commerce Act barred contracts regarding pooling of freight or 
division of profits, it said nothing about rate setting organizations. Indeed, the Trans-Missouri group filed its agreement with the ICC as required by Section 6 of the Commerce Act.

The Supreme Court decided Trans-Missouri on March 22, 1897. In a 5-4 decision, the Court rejected both the idea that railroads were somehow exempt from the Sherman Act given the more direct regulatory structure set forth in the Commerce Act and that the Sherman Act condemned only unreasonable restraints of trade. Understanding the language of the Sherman Act to have meant what it "plainly imports"-condemning all restraints of trade - the Court condemned the private rate setting of the railroad association and squarely inserted the Sherman Act into the everyday economic life of the country.

Where did that leave rate setting for railroads? Two months later, on May 24, 1897, the Court announced its opinion in Cincinnati, New Orleans, and Texas Pacific Railway (167 U.S. 479, 1897). This case considered whether the ICC had the power to set rates. Yes, the Commerce Act required rates to be "reasonable and just" and declared unreasonable and unjust rates unlawful. Yes, the Interstate Commerce Commission was to enforce the act, but the statute only expressly authorized the commission to issue a cease-anddesist order. The Supreme Court held that the ICC could do no more than that and that the ICC lacked the affirmative power to set rates. The power to set rates, said the Court, was "a legislative, and not an administrative or judicial, function" and given the stakes, this meant that "Congress has transferred such a power to any administrative body is not to be presumed or implied from any doubtful and uncertain language."

Thus Trans-Missouri turned private collective railroad rate setting into an antitrust violation, and under the Cincinnati ruling, the ICC could do no more than reject rates. Where would rate-setting authority lie? The Sherman Act was to be enforced in the courts, and through its decisions, the Supreme Court had severely constrained the ICC (Rabin 1986). At one level, the Trans-Missouri decision dominated railroad and antitrust policy for the next decade; at another level, the decision was largely irrelevant. As to the latter, the Interstate Commerce Commission stated in its 1901 annual report:

It is not the business of this Commission to enforce the antitrust act, and we express no opinion as to the legality of the means adopted by these associations. We simply call attention to the fact that the decision of the United States Supreme Court in the Trans-Missouri case and the Joint Traffic Association case has produced no practical effect upon the railway operations of the country. Such associations, in fact, exist now as they did before those decisions, and with the same general effect. In justice to all parties we ought probably to add that it is difficult to see how our interstate railways could be operated, with due regard to the interests of the shipper and the railway, without concerted action of the kind afforded to these associations. (15th Annual ICC Report, January 17, 1902, p. 16) 
But in another way, the Trans-Missouri decision framed the country's consideration of the trust question and the related question of how to grapple with large agglomerations of capital, as Sklar (1988) demonstrates in his history of the period. This decision seemingly satisfied no one.

\subsubsection{Solving Trans-Missouri}

If the ICC was right - if the economic structure of railroads required coordinated rate setting, either privately or through the government - the path forward was through revised legislation. Theodore Roosevelt became president when McKinley was assassinated in September 1901. In February 1903, Roosevelt moved forward on two fronts. The Elkins Act of 1903 gave the Interstate Commerce Commission the independent authority to seek relief in federal courts in situations in which railroads were charging less than published rates or were engaging in forbidden discrimination. Under the original Commerce Act, the ICC could act only on the petition of an injured party. The Elkins Act increased the ICC's power, but it still did not have an independent rate-setting power. Three years later, the Hepburn Act of 1906 took a first step in that direction. It added oil pipelines to the substantive scope of the act, and gave the ICC the power to set maximum rates, once it had found a prior rate unjust and unreasonable.

But Roosevelt, unwilling to rely solely on the Sherman Act to control general competition policy, was also looking for a way to exert more regulatory pressure on the rest of the economy. On February 14, 1903, Congress created a new executive department to be known as the Department of Commerce and Labor. Within the new department, the statute created the Bureau of Corporations. The bureau was designed to be an investigatory body with power to subpoena whose mission was to investigate any corporation engaged in interstate commerce to produce information and recommendations for legislation. But all of this information was to flow through the president, who in turn had the power to release industries from scrutiny. Railroads were expressly excluded. The design of the Bureau of Corporations matched Roosevelt's conception of the presidency as the bully pulpit. The bureau would give Roosevelt the information that he needed to go to the public or to Congress, plus the fact that the release of the information was within Roosevelt's power gave him leverage in negotiations with corporations.

After winning the presidency in 1904, Roosevelt continued to pursue his progressive agenda. Roosevelt called for an expansion of federal control over railroads - greater control over entry and issuance of securities, while allowing private railroad agreements on rates subject to approval by the Interstate Commerce Commission. At the same time, Roosevelt wanted a broad expansion in federal powers over large corporations engaged in interstate activities. He called for a federal incorporation law, or a federal licensing act, 
or some combination of the two. But by 1909, the Hepburn Bill, Roosevelt's vehicle for these changes, was dead in committee, and with it died Roosevelt's attempt for greater direct federal regulation of competition policy.

William Howard Taft succeeded Roosevelt as president in 1909. Taft supported the Mann-Elkins Act of 1910, which created a new, limited subject matter jurisdiction court, the United States Court of Commerce. It was staffed with five judges from the federal judiciary. The new Commerce Court was given exclusive jurisdiction of all appeals from ICC orders and appeals from the Commerce Court went to the Supreme Court.

Consider the Commerce Court in light of our prior general analysis of the choice between agencies and courts. Our earlier discussion suggested that federal courts of general jurisdiction would be poorly situated to deal with network industries. As Frankfurter and Landis $(1928,154)$ recognized, federal courts of general jurisdiction resulted in "conflicts in court decisions begetting territorial diversity where unified treatment of a problem is demanded, nullification by a single judge, even temporarily, of legislative or administrative action affecting whole sections of the country." A federal court of specialized jurisdiction would make possible many of the benefits of agencies - in particular, the ability to make coherent, contemporaneous decisions - while creating more independence than an agency would have.

The new Commerce Court took over a large number of cases then spread throughout the federal judiciary. The court was instantly busy and, almost as quickly, reviled by the public (Ripley 1913). The Commerce Court became the flashpoint for the "railroad problem"; as Frankfurter and Landis (1928, 164) put it, "[p]robably no court has ever been called upon to adjudicate so large a volume of litigation of as far-reaching import in so brief a time."

The Commerce Court failed. The public saw the ICC as protecting shippers from the power of the railroads, while the Commerce Court frequently overturned ICC decisions to the detriment of shippers. As Kolko $(1965,199)$ puts it in describing a series of Commerce Court decisions that were seen to benefit the railroads, "the Commerce Court proceeded to make itself the most unpopular judicial institution in a nation then in the process of attacking the sanctity of the courts." When Woodrow Wilson became president, he quickly signed legislation ending the Commerce Court, which came to final death on December 31, 1913. Its demise illustrates the power of shippers to protect themselves in ways that antitrust could not.

Wilson's presidency brings the process of structural reform to a close. The Supreme Court's 1911 decision in Standard Oil had already muted some of the pressure for antitrust reform. That decision abandoned the literalism of Trans-Missouri and introduced (restored?) the common law distinction between reasonable and unreasonable restraints of trade. (And, by the way, also broke up Standard Oil.) Early in his first term, on January 20, 1914, Wilson delivered a special message to Congress on antitrust. Wilson had 
two principal aims. First he wanted to make explicit the nature of antitrust violations:

Surely we are sufficiently familiar with the actual processes and methods of monopoly and of the many hurtful restraints of trade to make definition possible - at any rate up to the limits of what practice has disclosed. These practices, being now abundantly disclosed, can be explicitly and item by item forbidden by statute in such terms as will practically eliminate uncertainty, the law itself and the penalty being made equally plain.

Wilson then turned to the idea of an interstate trade commission:

And the business men of the country desire something more than that the menace of legal process in these matters be made explicit and intelligible. They desire the advice, the definite guidance and information which can be supplied by administrative body, an interstate trade commission. ("President Wilson's Message on Trusts," New York Times, January 21, 1914, p. 2.)

Later that year, Wilson got exactly what he wanted with the enactment of the Federal Trade Commission Act (FTCA) and the Clayton Act. Adopted on September 26, 1914, the FTCA brought to a close Roosevelt's efforts to extend the Interstate Commerce Act to the general economy. The Bureau of Corporations, designed by Roosevelt as the president's private investigatory arm, was to become the back office of the new Federal Trade Commission. The commission itself was to parallel the Interstate Commerce Commission: an independent agency of five commissioners appointed by the president on the advice and consent of the Senate.

Section 5 of the FTCA declared unlawful "unfair methods of competition" and empowered the FTC to prevent the use of such methods other than by banks, subject to the new banking act, and common carriers subject to the Commerce Act. In so doing, Section 5 tracked the Commerce Act in two ways: the FTCA focused on unfairness - typically measured by comparing the treatment of two similarly situated market participantswhile denying broader rate-setting power to the FTC. And the Clayton Act forbade specific practices, including tying and price discrimination. So Wilson got the specificity he wanted through the Clayton Act, and a general regulatory agency devoted to all industry through his new Federal Trade Commission. Industry would have a regulatory agency that it could turn to and perhaps even influence, though without the power to enforce industry cartels through the setting of rates or through limitations on entry, many of the critical anticompetitive harms that might result from capture were taken off of the table. The FTC, unlike industry-specific regulatory bodies, deals with industry in general. Perhaps this explains why, at least today, we are unaware of claims that the FTC has been captured by any industry or special interest group. Its structure raises the issue as to whether a combination of antitrust and industry-specific regulation in one agency, as occurs 
today in Australia or Europe for certain functions, is desirable — an issue we leave for future research.

With the 1914 legislation, the key institutional features that still dominate US antitrust law were established: the Sherman Act, the Clayton Act, and the FTC Act. The balance between antitrust and regulation still had to be worked out. The resolution of the issue of Trans-Missouri would take some time. The Transportation Act of 1920-finally-gave the Interstate Commerce Commission full control over rates, requiring the commission to ensure that rates permitted carriers to receive "a fair return upon the aggregate value of the railway property of such carriers held for and used in the service of transportation." As to the fight over whether antitrust or regulation ultimately controlled rate setting for railroads, in 1948, more than a half century after the Supreme Court's original decision in Trans-Missouri, Congress finally put the decision to rest by exempting joint setting of railroad rates from the antitrust laws, so long as the ICC approved the rates (Pub. L. 80-662, 62 Stat. 472 [June 17, 1948]).

\subsection{Modern Approaches to Network Industries}

We now jump from the formative years of the creation of competition policy to more recent times. Just as the initial battles between regulation and the Sherman Act illustrate the battle between antitrust and regulation as two methods to control competition, so too do more recent events - particularly the recent shift away from regulation to reliance on the Sherman Act. We focus our attention on network industries, since those are the ones where the case for regulation was often thought to be the strongest. If rate setting was the first great issue of competition policy for network industries, the leading issues today in network industries that continue to be heavily regulated are interconnection and mandatory access.

This recent history highlights a move away from regulation toward antitrust as a means to control competition and reveals how regulation and antitrust can be both substitutes and, in some settings, complements. The substitution involves the complete replacement of regulation with antitrust, as occurs when industries become deregulated (e.g., airlines and trucks). The complementarity between regulation and antitrust can arise in two ways. In an industry that becomes partially deregulated, antitrust can be used to control the unregulated segments, while regulation controls the rest. Indeed, partial deregulation of an industry can increase the importance to a rival of continuing rules of interconnection.

In structuring an efficient partial deregulation of an industry, the assignment of tasks to antitrust versus regulation is key. We should not ask antitrust and federal judges to perform tasks for which they are ill suitednamely price setting and crafting affirmative duties because those tasks 
require specialized industry knowledge that judges lack. If we need government involvement in those tasks, they should be assigned to regulators with specialized industry knowledge, though in making that judgment we need to recognize the inefficiencies that can arise as regulators cater to special interests or make mistakes. This is an especially serious problem in industries undergoing rapid technological change, where mistakes can impose huge costs. But it may be a mistake to just trump antitrust entirely, as we should fear capture of regulators, and that leads to a second type of complementarity.

The second form of complementarity between antitrust and regulation involves the use of antitrust as a constraint on how regulation is implemented. This is often implemented through a double filter or double-veto process, as we see in telecommunications mergers. The FCC evaluates telecom mergers under a public interest standard and that empowers the FCC to consider a wider range of issues than we typically entrust to federal judges. This would include, for example, whether and how to implement cross subsidies. But given the fear of regulatory capture, we apply a second, antitrust filter to these mergers by allowing the Department of Justice to sue under the antitrust laws to block an anticompetitive merger that the FCC has approved. Exactly how much scrutiny should be applied to regulatory decisions turns on a trade-off between allowing expertise to work-FCC expertise and knowledge-versus fearing biased decision making from an agency subject to capture. Even if no antitrust suit occurs, the threat of such a suit can influence FCC policy.

In this section, we address the fundamental question that has occupied and continues to occupy regulatory and antitrust decisions in network industries: How should those markets be structured and specifically how should firms interact in those industries? We focus our analysis on telecommunications and transportation (planes, trains, and trucks), though we note that interconnection issues are important in other industries such as electricity, where generators must have access to the transmission grid.

As already explained, a regulation may allow elevated pricing in return for some other objective that the regulator is likely to have to satisfy, such as a cross subsidy to different customer groups. But in order to achieve its objectives, the regulator may need to also control entry. Otherwise there may be no way to maintain the elevated price. This means that the regulator wants to limit competition and for that reason will be hostile to being constrained by the antitrust laws.

The regulators' concern with entry is especially acute in network industries in which firms may interconnect with each other, such as airlines, trucking, electricity, railroads, and telecommunications. In such industries, the regulator needs to administer the price and quality of the interconnection. If two firms compete in the end market and one competitor supplies the other 
a key input, the regulator must worry that the supplier will misuse its control over the input to harm his rival. This concern vanishes if the regulated firms are not allowed to vertically integrate. Moreover, when regulated firms must interconnect, the price of interconnection will typically be regulated to be above marginal cost. If so, there will be an efficiency motivation for a firm to vertically integrate to avoid double marginalization. But such mergers would eliminate firms and ultimately lead to one firm. Regulators might prefer to avoid this outcome to prevent one firm from becoming a potent political force in regulatory battles. ${ }^{3}$

By observing what happens when regulations are lifted, we can get a sense for why it was important to the regulators to constrain the forces of competition. We look at a few regulated network industries in the following. They all show a similar pattern: after either partial or complete deregulation, there is massive consolidation, increased industry concentration, an end to cross subsidy, often a decline in employment or wages, and a fall in price. Deregulation can be seen as the result of a consensus that regulation imposed high costs on the economy and that courts are sensibly applying the antitrust laws. Indeed, there is a recognition that the use of economics has revolutionized and made more sensible the antitrust laws. ${ }^{4}$ In light of the costs of regulation and the improvement in antitrust, a movement away from regulation toward antitrust has occurred. In this view, regulation and antitrust are substitutes. But in some cases we also see regulation and antitrust being used together in an industry, illustrating the possible complementarity use of the two.

\subsubsection{Telecommunications}

\section{Early Interconnection Battles}

The telephone system is about interconnection, as a single-phone phone system is worthless. In the early days of the industry, as Mueller (1997) describes, different local companies competed with each other. A customer of one company could reach other customers of only that company; you might need to have multiple phones to reach everyone. (This is very much like instant messaging several years ago, where America Online resisted

3. In an industry with high sunk costs but low marginal costs, interconnection fees based on models of contestability fail to reward carriers adequately for risk, since contestability ignores sunk costs. In such situations, not only is price above marginal cost, but investment is deterred. This may have been the case in telecommunications. See Pindyck (2008).

4. As Posner (2003) explains in the preface to the second edition of his primer Antitrust Law:

Much of antitrust law in 1976 was an intellectual disgrace. Today, antitrust law is a body of economically rational principles largely though not entirely congruent with the principles set forth in the first edition. The chief worry at present is not doctrine or direction, but implementation.(viii) 
attempts by Yahoo, Microsoft, and others to create a unified IM system [Festa 2000].) American Telephone and Telegraph — the Bell System - was the dominant firm of the day, but local competition was widespread; indeed, during the early 1900s, half of the cities with populations larger than 5,000 had competing local firms (Mueller 1997, 81). This competition almost certainly had benefits - on price and service - but came with a loss of network externalities. AT\&T set out to build a universal system and started by purchasing competing telephone companies.

In 1912, that led to an antitrust suit in Portland, Oregon, and to calls by the postmaster general to nationalize the telephone and telegraph systempresumably to unify the messaging systems of the day (postal, telegraph, and phone) into one set of hands. Faced with these two threats, AT\&T agreed to, in the words of N. C. Kingsbury, an AT\&T vice president, "set its house in order." In what is now known as the Kingsbury Commitment, AT\&T agreed to divest itself of control over Western Union; to stop acquisitions of competing lines; and to give access to Bell's long-distance lines to competing local phone companies, that is, to interconnect the Bell system's long distance lines with the local competitor's network. ${ }^{5}$

The Kingsbury Commitment might be framed as a victory for local phone competition but for two factors. First, few phone users made long-distance calls, so the local line/long-distance line interconnection may not have been an important competitive factor. Second, the size of the local network did matter, and AT\&T aggressively moved forward on local interconnection, something outside the scope of the Kingsbury Commitment.

As is so often the case, antitrust action-here, the settlement-sets the stage for the next round of legislation, and that emerged in the form of the Willis-Graham Act of 1921. The new law entrusted telephone mergers to the Interstate Commerce Commission and authorized approval if doing so would "be of advantage to the persons to whom service is rendered and in the public interest." The act also added a sharp boundary between antitrust and regulation: once the ICC had said yes, the Department of Justice and the Federal Trade Commission could do nothing. With the new act in place, AT\&T moved swiftly to create local interconnection through acquisition, with the ICC approving 271 of 274 AT\&T acquisitions over a thirteen-year period (Starr 2004, 209). ${ }^{6}$

\section{Interconnection Again: MCI's Entry into Long Distance}

We jump ahead to consider the entry of MCI into long distance. We start with a single integrated phone system, with local and long distance controlled by AT\&T. MCI entered in a very limited way, by building microwave

5. See "Government Accepts an Offer of Complete Separation," New York Times, Dec. 20, 1913, 1 (setting forth terms of the Kingsbury Commitment).

6. For a more detailed look at the early history of the telecommunications industry, see Weiman and Levin (1994). 
towers to enable private within-firm phone calls between St. Louis and Chicago (say, between Walgreens's home office in Chicago and a district office in St. Louis). MCI did not need access to the public network to make this work. Even this limited entry required an initial 1959 order and a subsequent 1969 ruling from the Federal Communications Commission.

Unlike entry into private lines, entry into the public market for long distance required $\mathrm{MCI}$ to interconnect with AT\&T, or in the alternative, simultaneous entry by MCI into local and long distance. And if MCI had been forced to build the entire network, it could not likely have entered the market. The local network was seen as a natural monopoly. It clearly would have been inefficient to build a second local network - that just says again that the local network was a natural monopoly - and it was also probably the case that it was a money-losing proposition for MCI to build a local network.

Bundling entry - forcing MCI to enter on the scale of having to build a local network if it wanted to enter the long-distance business-would probably have prevented the long-distance entry. Unbundling entry - giving $\mathrm{MCI}$ access to the local network while allowing entry only in long distancemeant that MCI could just compare the much more limited capital costs of building the second piece with the profits associated with that piece rather than the costs of both pieces with the profits associated with both pieces.

MCI moved against AT\&T on both regulatory and antitrust fronts. In 1970, the FCC had concluded that some entry was appropriate, but when push came to shove, the FCC backtracked. In February 1978, the FCC rejected MCI's request that AT\&T be ordered to provide local physical interconnections for MCI's intended public long-distance service. AT\&T successfully persuaded the FCC that MCI would target high-profit routes and that that would destabilize the existing structure of rates, contrary to the public interest. MCI successfully appealed to the DC Circuit, which concluded that the consequences of entry could be dealt with on a case-by-case basis. In a subsequent proceeding, in 1978, the DC Circuit ordered AT\&T to make interconnection for MCI's long-distance service.

MCI filed a private antitrust suit against AT\&T in 1974. That case eventually went to a jury trial in the first half of 1980 . The jury ultimately found AT\&T liable on ten of fifteen charges, and awarded $\$ 600$ million in actual damages, then trebled to $\$ 1.8$ billion under Section 4 of the Clayton Act. On interconnection, MCI successfully argued that AT\&T's refusal to interconnect constituted an impermissible refusal of access to an essential facility. The Seventh Circuit sustained the jury finding that this refusal constituted monopolization in violation of Section 2 of the Sherman Act.

We should step back from the details of this fight over entry and interconnection to focus on the interaction between regulation and antitrust. In general we know that regulation can lead to cross subsidy. Cross subsidies create entry incentives. General antitrust law will often facilitate entry but will do so with little regard for the cross-subsidy issues. MCI's entry into 
long distance probably fits in this framework. The DC Circuit expressly considered the cross-subsidy issues as part of its review of the FCC's regulatory proceedings, but concluded that those issues could be dealt with in subsequent proceedings. In contrast, the Seventh Circuit, faced with antitrust claims (and not regulatory claims) could not consider what its interconnection ruling might mean for the existing set of cross-subsidized rates. This is an excellent illustration of the use of antitrust in a regulated industry to control competition, where antitrust constrains what regulation can do.

Whether we should have welcomed MCI's entry is a separate question. To assess that, we need to assess what goals the regulators were pursuing and if those goals were sensible. MCI's entry precipitated a decline in longdistance rates. If prior to that decline, the regulators were pursuing the "public interest," then MCI's entry constrained the regulators from pursuing their desired policy. If we start with a regulated monopolist offering services to different customers, the regulator will need to set prices for each group of customers. The standard response in theory is Ramsey pricing. The regulator sets a series of prices - prices for long distance and for local service, for business customers and consumers, for urban and rural users - to minimize social loss while hitting a revenue target. The Ramsey approach is about allocating the fixed costs of production among the different groups using the service. The simple theory says that inelastic demanders should pay a larger share of the fixed costs. Inelastic demanders will not change their purchases much in the face of higher charges, and it is the reduced consumption when we push prices above marginal cost that causes the social loss. In order for elastic demanders to not bear too many fixed costs, inelastic demanders should pay a big chunk of those costs.

Now assume that we have put Ramsey prices into place. Those prices can create arbitrage opportunities: indeed, the whole vision behind Ramsey pricing is that inelastic demanders bear the brunt of fixed costs, while elastic demanders bear few of those costs. Ramsey pricing is precisely about price discrimination. If the regulators get the prices "right" in the first instance, we may nonetheless see entry that emerges because of regulator-created price gaps that are eliminated by the entry (see Faulhaber 1975). This entry would be undesirable if we accept the regulators' goals. This concern with "cream skimming" was prevalent in contemplating long-distance entry.

The regulators may not have implemented Ramsey prices in the first instance, but they clearly had created an elaborate pattern of cross subsidies, and that pattern would become more difficult to sustain after entry. How should we evaluate entry, whether facilities-based competition or otherwise, where the entry opportunity is created by cross-subsidy-driven pricing? To some extent, this requires a political account - a public choice accountabout the nature of subsidies. If we thought that the subsidies were appropriate, then we should bar entry occurring just because of the opportunity created by the cross subsidy. So if the incumbent charges a higher price in 
urban areas than costs would warrant but does so because of a requirement that the price structure force urban users to subsidize rural users, entry targeted at urban users should be seen as problematic. In contrast, if we think of cross subsidies as inappropriate, entry may be useful in that it may make those subsidies unsustainable.

\section{The 1996 Act's Access Rules and Trinko ${ }^{7}$}

With the rise of AT\&T's dominance, despite the passage of the Communications Act of 1934, antitrust became the main vehicle for altering the structure of AT\&T. In 1949, the federal government brought an antitrust action against AT\&T, which, in turn, resulted in a 1956 consent decree and final judgment. In 1974, the government brought a new action against AT\&T, and in 1982, a new consent decree emerged as a modification of the 1956 decree. That decree resulted in the break up of AT\&T: long distance was separated from local and regional local companies were established. (Though we will not discuss it, the breakup of AT\&T has received much attention. See Noll and Owen [1989].)

We want to focus on the next important event, namely the Telecommunications Act of 1996. The 1996 act is wide ranging, but we address only its efforts to produce local competition through a strong access policy and focus on the interaction of antitrust and regulation. The 1996 act seeks to facilitate competition in local telephone markets by making it easier for entrants to compete with incumbents. It does so by creating a series of mandatory dealing obligations; that is, ways in which the incumbent is required to share its facilities with an entrant. This includes an obligation of interconnection; a requirement to sell telecommunications services to an entrant at wholesale prices, so that the entrant can resell those services at retail; and an obligation to unbundle its local network and sell access to pieces of the network at a cost-based price.

As to the intersection of the 1996 act and antitrust, the 1996 act contains a "savings" clause:

Nothing in this Act or the amendments made by this Act ... shall be construed to modify, impair, or supersede the applicability of any of the antitrust laws. (47 U.S.C. § 152, Historical and Statutory Notes.)

In January 2004, the Supreme Court announced its opinion in Trinko. AT\&T wanted to enter Verizon's local markets in New York and sought access pursuant to the terms of the then-applicable rules under the 1996 act. When the access granted was seen as inadequate, both state and federal communications regulators acted and monetary penalties were imposed against Verizon. Enter Curtis Trinko, a New York lawyer. He brought an antitrust

7. Carlton has served as an expert for major telecommunications companies including AT\&T and Verizon, and consulted on Trinko. 
class action against Verizon alleging that, as a local customer of AT\&T, he was injured by Verizon's actions and that those actions violated Section 2 of the Sherman Act. The federal district court would have none of that and booted the complaint, but the Second Circuit reversed.

Justice Scalia, for the Court, noted that the situation seemed to call for an implicit antitrust immunity. The 1996 act created access duties and those duties could be enforced - and were enforced here - through the appropriate regulators. That would seem to suffice, and there would be some risk that additional antitrust enforcement would interfere with the regulatory scheme. So the Court might have held, but for the savings clause, which precluded such a claim of implicit immunity.

Instead, the Court turned to the question of whether antitrust law, as distinct from regulation, imposed on Verizon a duty to deal with entrants. Antitrust rarely imposes mandatory obligations, other than as a remedy for an independent antitrust violation. The Aspen Skiing case represents one prominent exception to that statement, and whatever the merits of Aspen (see Carlton [2001] for criticism), the Court saw little reason to expand mandatory obligations here. Indeed, just the opposite: "The 1996 Act's extensive provision for access makes it unnecessary to impose a judicial doctrine of forced access." The Court ruled that the antitrust laws imposed no duty to deal on Verizon.

The savings clause reflects the idea of antitrust and regulation as complementary mechanisms to control competition. As suggested in the introduction to this section, Congress might want to implement complementarity as a way of imposing a check on the regulatory agents that implement particular industry legislation. The continuing applicability of antitrust law notwithstanding, the existence of industry-specific legislation imposes limits on how far industry regulators can deviate from the principles at stake in antitrust. The difficulty is in implementing that idea in a particular situation. In Trinko itself, the Court recognized that antitrust has only weakly embraced affirmative duties, with Aspen Skiing seemingly representing the outer limits for antitrust itself. Given antitrust's own deficits in the area of affirmative dealing, the Court wisely decided that Trinko would have represented a particularly poor situation to try to use antitrust to police errant telecom regulators.

\subsubsection{Airlines}

The airline industry, analyzed in great detail by Severin Borenstein and Nancy Rose in chapter 2 of this volume, provides another interesting case study of the interplay of regulation and antitrust policy. Congress established the Civil Aeronautics Administration, which later became the Civil Aeronautics Board (CAB), in 1938. The CAB regulated fares and entry. They cross-subsidized low-density short-haul routes with revenues from low-cost long-haul routes. The $\mathrm{CAB}$ rarely allowed mergers unless bank- 
ruptcy was imminent (Morrison and Winston 2000, 9). By the 1970s, the $\mathrm{CAB}$ began to allow entry. Several airlines were in the process of initiating lawsuits against the $\mathrm{CAB}$ for violating its congressional mandate, when the Airline Deregulation Act of 1978 was passed. (Interestingly, the largest domestic carrier at the time, United, favored deregulation.) Airline regulation was phased out and the CAB was abolished in 1984 (see Carlton and Perloff 2005).

In response to widespread criticism of regulation, airline competition was deregulated and controlled only by antitrust. As documented in chapter 2 by Borenstein and Rose, deregulation set in motion forces that are still working their way through the airline system. Fares fell substantially after deregulation with typical estimates being 20 percent or more (see also Morrison and Winston 2000,2). The menu of fares on a typical route grew. Cross subsidies were eliminated (the $\mathrm{CAB}$ had eliminated cross subsidies based on distance in the 1970s). There has been a virtual flood of entry and exit since deregulation. For example, of the fifty-eight carriers that began operations between 1978 and 1990, only one (America West) was still operating by 2000 (Morrison and Winston 2000, 9).

Airlines developed hub-and-spoke networks (with Southwest being a notable exception) through merger and internal expansion, and as a result reduced their need to rely on another airline for interconnection. For example, in 197925 percent of trips involved connections, and of those, 39 percent involved another airline. By 1989, there were more connecting flights as a result of the hub-and-spoke system, with the effect being that 33 percent of trips involved connections, and of those, less than 5 percent involved an interconnection with another airline.

There was considerable merger activity and agreements among airlines to cooperate on flight schedules and the setting of through-fares when a passenger travels on two airlines to reach his final destination. (These agreements are called alliances or code-sharing agreements.) The Department of Justice challenged several mergers and alliances in the period between 2000 and $2010 .{ }^{8}$ For example, its opposition ended the attempt of United to merge with US Airways.

As a result of mergers and firm expansion, concentration has risen nationally since deregulation. According to Borenstein (1992), the national fourfirm concentration ratio rose from 56 percent in 1977 to 62 percent in 1990. As of 2011, it was 66 percent according to the US Department of Transportation (2011), but concentration at hubs has behaved very differently than concentration at nonhubs. At hub airports, the Herfindahl-Hirschman Index (HHI) rose from a median of under 2,200 pre-deregulation to a median of 3,700 by 1989, while at nonhub airports, the HHI fell from 3,200 in 1979 to about 2,200 in 1989 (Bamberger and Carlton 2003). As of 2011,

8. Carlton has served as an expert for the major airlines in mergers and other proceedings. 
median HHI at hub airports was 5,400, while median HHI at nonhub airports was $2,300 .^{9}$

Despite regulation, airlines proved to be a poor investment. During regulation, especially the 1970s, service competition eroded a significant portion of airline earnings. Since deregulation, fierce price competition has led to the bankruptcy of several airlines and indeed several major airlines were recently either in bankruptcy or are close to it. ("As of 1992 . . , the money that has been made since the dawn of aviation by all of this country's airline companies was zero. . . . I like to think that if I'd been at Kitty Hawk in 1903, I would have been farsighted enough and public spirited enough-I owed this to future capitalists - to shoot him down" [Warren Buffet, as reported in Loomis (1999)]). The US domestic airline industry lost, in 2009 dollars, $\$ 10$ billion from 1979 to 1989 , made $\$ 5$ billion in the 1990s, and lost $\$ 54$ billion from 2000 to 2009 (Borenstein 2011). Deregulation also led to lower wages for employees and increased productivity.

The behavior of the airline industry post-deregulation illustrates that a once-regulated industry may be prone to antitrust violations in the aftermath of regulation. This could occur because collective action is needed for efficiency or simply because firms in the industry have gotten used to acting in concert during regulation. We think the airline industry illustrates well the heightened antitrust liability that can attend a network industry when it is deregulated.

Prior to deregulation, airlines relied on each other to interconnect passengers. That meant that airlines would have to set some fares jointly and decide how to split the revenue. So, for example, if airline 1 flies from A to B, and airline 2 flies from $B$ to $C$, the two airlines could coordinate their flight times so that a traveler could conveniently go from $A$ to $C$ (with a change of plane at B). The two airlines would collectively set a fare for A to C travel and share it in some way. Also, airlines, postregulation, developed sophisticated pricing methods requiring booking agents to keep track of multiple fares and seat availability.

This created two problems. First, travel agents needed complex software to allow them to book tickets. Second, travel agents had to have up-to-date information on pricing and seat availability. Thousands of fares existed and many changed daily. The pricing of airlines sometimes involved large swings in price and its pricing is more complicated than pricing in many other markets. These characteristics created the incentive for certain acts that could achieve efficiencies but might also be used to harm competition. Significant antitrust litigation against the airlines ensued post-deregulation.

The tendency of airlines to cooperate in the setting of through-fares when traffic is shared can be a natural and desirable way for two airlines to provide a service to consumers that neither airline, on its own, could provide. It could

9. Data from Database Products Inc. These calculations for hub and nonhub airports are limited to the top 100 US airports. 
also be a ploy by which one airline bribes another to prevent expansion of competing routes. (For example, if you do not enter route BC, where I fly, I will interline with your $\mathrm{AB}$ route and let you keep a large fraction of the through-fare from A to C. In that way, you have no incentive to enter BC and compete with me on that route.) This last concern motivates the Department of Justice to investigate proposed domestic airline alliances for possible antitrust harm.

The need for software to book tickets led to several cases and investigations into computer reservation systems (CRS), where the concern was that the CRS used by a travel agent favored the airline that produced the CRS. So, for example, if a travel agent used the Sabre system originally developed by American Airlines, that system displayed information about American Airlines flights more prominently than other airlines. As a result of the government investigation, detailed rules on "unbiasedness" were agreed to (see Guerin-Calvert and Noll 1991) but are no longer in force. Today, CRSs are no longer privately owned by the airlines. ${ }^{10}$

The need to have updates of the massive number of daily fare changes led to a Department of Justice investigation of information sharing amongst the airlines. Most of the airlines would provide information each day on all their fares by route. The information in a "notes section" would contain relevant fare restrictions (e.g., weekend stays, advance purchase requirements) as well as the date the fare became effective and expired. This information on fares was transmitted to the Airline Tariff Publishing Company (ATPCO) which then made a master computer tape and distributed it to all airlines and travel agents. The ATPCO was owned by the airlines.

The Department of Justice alleged that the ATPCO was being used as a mechanism to coordinate pricing. One allegation was that the notes section was used to communicate price signals. So, for example, if airline 1 cut price on an important route of airline 2 , airline 2 would retaliate and cut price on an important route of airline 1 . To make sure airline 1 understood why it had cut fares, airline 2 could put a note to indicate why it had cut price in an attempt to convince airline 1 to withdraw its low fares on airline 2's routes.

A related allegation was that the first effective and last effective ticket date were used to make it easier to coordinate pricing. So, for example, if airline 1 wanted to raise fares, it would announce an increase to take effect in, say, two weeks. If other airlines did not match, or only partly matched, airline 1 could rescind or revise its fare increase and not suffer any loss of business because the fare increase had not yet gone into effect. The airlines denied the government allegations. ${ }^{11}$ The airlines settled the case by agreeing to

10. There have been antitrust suits in which biasing, among other issues, has been alleged. See, for example, American Airlines, Inc., vs. Travelport Inc., Sabre, Inc., Sabre Holdings Inc., and Sabre Travel International Ltd. in the District Court of Tarrant County, 67th District Court, Cause No. 67-249214-10. Carlton has served as an expert for American Airlines.

11. Carlton served as an expert for the airlines. 
eliminate extraneous notes and by abandoning the use of first ticket dates. Interestingly, analyses of fares shows no lasting effect from the investigation and settlement (Borenstein [2004] and Miller [2010], though Miller [2010] finds some evidence of a temporary improvement in competition).

The sometimes wild price swings that occur when new entrants start servicing a route has led to both litigation and government investigations. In a city pair that can support only one or a few carriers, competition from a new rival not only can expand capacity a lot but can induce reactions from the incumbents. In response to an aggressive price and output reaction by an incumbent, allegations of predation are often made. The precise definition of predation in an industry such as airlines with large fixed costs on a route but small variable costs is not well established, especially on a route where only one carrier can survive (Edlin and Farrell 2004). But the observation that fares frequently plummet below levels that are financially viable has led to demands for government intervention.

In U.S. v. AMR et al. (140 F. Supp. 2d 1141 [2001], aff'd, 335 F.3d 1109 [10th Cir. 2003]), the Department of Justice accused American Airlines of practicing price predation. American Airlines competed out of Dallas Fort Worth with several low-cost airlines (Vanguard, Western Pacific, Sun Jet). American lowered its fares, and increased its seat availability in response to these low-cost airlines, causing them to abandon their routes. After the low-cost airlines exited, American reduced the number of flights and raised prices to roughly their initial levels. American responded that its prices exceeded average variable costs, and moved for summary judgment, which was granted.

Just prior to the Department of Justice case, the Department of Transportation initiated an investigation of predation in the airline industry. It investigated several incidents in which it was alleged that incumbents routinely responded to entry of low-cost carriers by lowering fares, expanding output, and driving them out of business, at which point fares rose. In a detailed study of entry and exit patterns (submitted to the Department of Transportation on behalf of United), Bamberger and Carlton (2006) found that entry and exit on routes were extremely common amongst both low-cost carriers and established carriers. Moreover, with the exception of Southwest Airlines, there were very high exit rates amongst both low-cost and regular carriers. The Department of Transportation dropped its attempt to define predation standards. Between 2000 and 2011, the share of passengers served by Southwest Airlines rose from 12 percent to 17 percent. (As an aside, between 2000 and 2011, the share of passengers served by low-cost airlines rose from 18 percent to 27 percent. $)^{12}$

12. Low-cost carriers include: Airtran, America West, JetBlue, Midway, Southwest, Spirit, Sun Country, Virgin America, Allegiant, USA3000, National, and World. Data from US Department of Transportation, T1 US Air Carrier Traffic Statistics. 


\subsubsection{Railroads ${ }^{13}$}

As Gilligan, Marshall, and Weingast (1989) note, the consequences of the Interstate Commerce Act are complex. One view is that it was a mechanism to benefit the railroads. But as with most regulated industries the regulators had other interest groups to satisfy, and they did. Cross subsidy to high-cost, low-density routes and to short-haul shippers emerged. Price discrimination in which high value-added products had higher rates than bulk also emerged to placate certain shipper interest groups. In what was to be important later, regulators controlled not only entry but also exit from a route. The emergence of the truck (and airplanes) complicated the regulatory calculations.

Control of trucking became necessary to protect railroads and did occur in the Motor Carrier Act of 1935. As trucking (especially its union, the Teamsters) developed as its own powerful interest group, the interest of railroads waned and railroads got clobbered financially, resulting in numerous bankruptcies. Trucks siphoned off the profitable high value-added shipments and eroded this source of revenue that railroads used for cross subsidy. The restrictions on abandonment of routes created enormous inefficiencies. The deregulation of the railroads in 1976 (4R Act) and in 1980 (Staggers Act) removed most regulations but placed merger control in the hands of the Surface Transportation Board (STB), not the Department of Justice. It streamlined the process for merging.

After deregulation, there was massive abandonment of track, reductions in employment, decline in certain rates, and massive consolidation that is still ongoing. Roughly one-third of tracks were abandoned, real operating costs fell in the twenty-year period following deregulation by about 60 percent, employment has been estimated to be about 60 percent lower as a result of deregulation (Davis and Wilson 1999), rail volumes started to grow again, and industry profitability improved. Rates fell (Burton 1993), especially for high value-added products, and service improved.

"Before deregulation, mergers typically involved railroads with substantial parallel trackage. . . . In contrast, mergers in the post-Staggers period have been primarily end-to-end" (Vellturo et al. 1992, 341-42). Mergers in the first six years of deregulation reduced the number of large railroads (Class I) from thirty-six to sixteen (Grimm and Winston 2000, 45-46, citing Chaplin and Schmidt 1999). Continued merger activity has left only two railroads servicing the West and also the East (see also Ivaldi and McCullough 2010). Using figures from the Association of American Railroads, the number of Class I railroads declined from thirty-six in 1978 to seven in 2002, where it remains. The industry's HHI, calculated on a national basis with car miles as the output, rose from 589 in 1978 to 2,262 in 2006 (Ivaldi and MCullough 2010). According to a study by the Department of Agriculture,

13. This section draws heavily from Peltzman (1989) and Grimm and Winston (2000). 
the HHI of railroads in the East increased from 1,364 in 1980 to 4,297 in 1999 and in the West from 1,364 to 4,502. ${ }^{14}$

Despite opposition from the Department of Justice to many of the major mergers, STB has approved them. We believe that the reason the STB was given merger authority rather than the Department of Justice is precisely because mergers were anticipated that would lead to increased rates from reduced competition, and this was perceived as a benefit by the proponents of deregulation (which included the railroads). "The railroad industry is perhaps the only US industry that has been, or ever will be, deregulated because of its poor financial performance under regulation" (Grimm and Winston $2000,41)$. Indeed, although railroads' rates in general have declined, captive shippers now have much less protection than before deregulation and pay substantial rate differentials compared to noncaptive shippers.

In March 2000, the STB issued a moratorium on mergers. In June 2001, it issued new merger regulations in which merged carriers would have an increased burden to show that the proposed merger would not harm competition. There have been no mergers among Class I railroads since. There have been congressional attempts to remove the antitrust immunity of railroads regarding mergers and other pricing matters (Gallagher 2006).

\subsubsection{Trucks}

As already discussed, trucking regulation emerged under the Motor Carrier Act of 1935 partly as an attempt to control competition with railroads. The trucking industry, especially its unions, was able to become a powerful interest group whom regulators protected from competition. (Estimates are that wages were 30 percent higher or more than otherwise and that this premium accounted for the bulk of the regulatory rents to trucking; see Rose 1987 and Moore 1978.) Entry was controlled with carriers needing certificates to carry certain commodities on particular routes. Rates were regulated.

The trucking industry is composed of two very different segments, truck load (TL) and less than truck load (LTL). The TL segment consists of firms that ship in truckloads from origin to destination. In contrast, the LTL segment consists of firms that will pick up several small shipments, and deliver them to their final destinations after making several stops to either pick up or drop off other shipments. Therefore, the LTL segment is a network industry where scale (or geographic scope) matters, while the TL segment is not. Deregulation had very different effects on these two segments.

Deregulation led to an increase in the total number of trucking firms. For example, the number of certified carriers rose from about 18,000 in 1980 to about 40,000 by the end of the 1980s (Nebesky, McMullen, and Lee

14. Data from comments of the US Department of Agriculture before the Surface Transportation Board, STB Docket No. 34000, Canadian National Railway Co. et al.-ControlWisconsin Central Railway Co., June 25, 2001. 
1995). In sharp contrast, the number of LTL carriers fell from around 600 firms in the late 1970s to 237 firms in the late 1980s, and to 135 firms by the early 1990s (Feitler, Corsi, and Grimm 1997). Moreover, there was evidence that pre-deregulation, LTL carriers earned rents that were eliminated after deregulation.

Although LTL carriers have increased in size, they did not rely on mergers but rather on expansion of the territory of individual carriers, often achieved through the purchase of a bankrupt carrier. (Mergers were not used in order to prevent the acquirer from being stuck with unfunded pension liabilities.) After deregulation, the market value of a trucking firm could become negative after the value of its operating certificate fell (Boyer 1993, 485). Although the evidence seems to confirm that regulation forced the LTL sector to have too many firms, evidence on scale in the LTL sector (Giordano 1997) supports the view that there will remain a sufficient number of efficient LTL carriers to preserve competition. Moreover, one factor limiting the rise in concentration was the growth in nonunion regional carriers at the expense of the unionized national carriers.

The deregulation of trucking applied to interstate but not intrastate shipments. States were able to, and some did, regulate rates and entry of intrastate trucking. Some states explicitly granted antitrust immunity, while others did not. (In the thirty-eight states that regulated trucking under 500 pounds, twenty-two had granted antitrust immunity to truckers as of 1987.) Econometric analysis (Daniel and Kleit 1995) of rates in the states that still regulated trucking showed that in the LTL segment, entry regulation raised rates by over 20 percent, rate regulation by over 5 percent, and antitrust immunity by about 12 percent. In the TL segment, only rate regulation had a statistically significant effect on price-more than 32 percent. As of 1994, congressional legislation forbids states from regulating trucking rates, except for moving companies.

Although employment in trucking continued to grow after deregulation, one estimate finds that deregulation caused a reduction of 250,000 to 300,000 union jobs, or about 20 percent of total workers in trucking (Hunter and Mangum 1995). This is further evidence that trucking regulation was heavily influenced by the powerful Teamsters Union. Moreover, the wage effect in the LTL segment was small but wages declined significantly in the TL sector (Belzer 1995).

Although we have not examined all regulated industries, we have looked at several. Regulation created numerous inefficiencies and benefited special groups. In response to criticisms of regulation, antitrust either completely or partially replaced regulation and antitrust was used as a complement and sometimes as a constraint on regulators in many industries. The deregulated network industries that we examined all show a similar pattern: after deregulation, there is massive consolidation, a lessening of the reliance on 
interconnection from other firms, a decline in either wages or employment or both, and a fall in prices with a reduction or end to any cross subsidy. Consumers benefit, special interests are harmed.

\subsection{Conclusion}

More than a century ago, the federal government started controlling competition, first railroads through the Interstate Commerce Act and then the general economy under the Sherman Act. The Commerce Act assigned primary responsibility to the first great federal agency, the Interstate Commerce Commission, while the Sherman Act relied for its implementation on federal courts of general jurisdiction. Since that time, there has been an ongoing struggle to formulate the appropriate policy for controlling competition and to determine the right balance between antitrust and regulation for implementing that policy.

Regulation and antitrust are two competing mechanisms to control competition. The early history in which special courts were established and then abolished and in which the FTC was created illustrate this point. The relative advantages and disadvantages of each mechanism became clearer over time. Regulation produced cross subsidies and favors to special interests, but was able to specify prices and specific rules of how firms should deal with each other. Antitrust, especially when it became economically coherent within the past thirty years or so, showed itself to be reasonably good at promoting competition, avoiding the favoring of special interests, but not good at formulating specific rules for particular industries. The partial and full deregulation movement was a response to the recognition of the relative advantages of regulation and antitrust. This does not mean that no sector will be regulated, but rather that competition, constrained only by antitrust, will be used over more activities, even in regulated industries.

Aside from being viewed as substitutes, antitrust and regulation can also be viewed as complements in which the activities of an industry can be subject to both regulatory and antitrust scrutiny. In this way, the complementary use of regulation and antitrust can assign control of competition to courts and regulatory agencies based on their relative strengths and, in some settings, antitrust can act as a constraint on what regulators can do. The trends in network industries indicate that regulators, not antitrust courts, will bear the responsibility for formulating interconnection policies in partially deregulated industries, but antitrust will remain in the background as a club that firms can use if regulators allow incumbents to acquire market power either through merger or predatory acts.

The history shows that at least for the United States, the increased use of the Sherman Act instead of regulation to control competition, and when necessary, the complementary use of the two, has brought benefits to consumers. 


\section{References}

Bamberger, Gustavo, and Dennis Carlton. 2003. "Airline Networks and Fares." In Handbook of Airline Economics, second edition, edited by Darryl Jenkins, 269-88. New York: Aviation Week, a Division of McGraw-Hill.

.2006. "Predation and the Entry and Exit of Low-Fare Carriers." In Advances in Airline Economics: Competition Policy and Antitrust, edited by Darin Lee, 1-23. North Holland: Elsevier.

Becker, Gary. 1983. "A Theory of Competition among Pressure Groups for Political Influence.” Quarterly Journal of Economics 98:371-400.

Belzer, Michael. 1995. "Collective Bargaining After Deregulation: Do the Teamsters Still Count?" Industrial and Labor Relations Review 48:636-55.

Benson, Bruce, M. Greenhut, and Randall Holcombe. 1987. "Interest Groups and the Antitrust Paradox." Cato Journal 6:801-17.

Bittlingmayer, George. 1985. "Did Antitrust Policy Cause the Great Merger Wave?" Journal of Law \& Economics 28:77-118.

Borenstein, Severin. 1992. "The Evolution of US Airline Competition." Journal of Economic Perspectives 6:45-73.

2004. "Rapid Price Communication and Coordination: The Airline Tariff Publishing Case." In The Antitrust Revolution, fourth edition, edited by John E. Kwoka and Lawrence J. White, 233-51. New York: Oxford University Press.

_.2011. "Why Can't US Airlines Make Money?" American Economic Review 101:233-37.

Boyer, Kenneth. 1993. "Deregulation of the Trucking Sector: Specialization, Concentration, Entry and Financial Distress." Southern Economic Journal 59:481-95.

Burton, Mark. 1993. "Railroad Deregulation, Carrier Behavior, and Shipper Response: A Disaggregated Analysis." Journal of Regulatory Economics 5:417-34.

Carlton, Dennis. 2001. "A General Analysis of Exclusionary Conduct and Refusal to Deal: Why Aspen and Kodak Are Misguided.” Antitrust Law Journal 68:659-83.

Carlton, Dennis, Alan Frankel, and Elisabeth Landes. 2004. "The Control of Externalities in Sports Leagues: An Analysis of Restrictions in the National Hockey League." Journal of Political Economy 112:S268-88.

Carlton, Dennis, and Jeffrey Perloff. 2005. Modern Industrial Organization, fourth edition. Pearson.

Chaplin, Alison, and Stephen Schmidt. 1999. "Do Mergers Improve Efficiency? Evidence from Deregulated Rail Freight." Journal of Transport Economics and Policy 33:147-62.

Daniel, Timothy, and Andrew Kleit. 1995. "Disentangling Regulatory Policy: The Effects of State Regulations on Trucking Rates." Journal of Regulatory Economics 8:267-84.

Davis, David, and Wesley Wilson. 1999. "Deregulation, Mergers, and Employment in the Railroad Industry." Journal of Regulatory Economics 15:5-22.

Edlin, Aaron, and Joseph Farrell. 2004. "The American Airlines Case: A Chance to Clarify Predation Policy (2001)." In The Antitrust Revolution, fourth edition, edited by John E. Kwoka and Lawrence J. White, 502-07. New York: Oxford University Press.

Faulhaber, Gerald R. 1975. "Cross-Subsidization: Pricing in Public Enterprises." American Economic Review 65:966-77.

Feitler, Jane, Thomas Corsi, and Curtis Grimm. 1997. "Measuring Strategic Change in the Regulated and Deregulated Motor Carrier Industry: An 18 Year Evaluation." Transportation Research Part E, Logistics and Transportation Review 33:159-69. 
Festa, Paul. 2000. "AOL Instant Messaging Efforts May Be at Cross Purposes." CNET News, May 15.

Fiorina, Morris. 1982. "Legislative Choice of Regulatory Forms: Legal Process or Administrative Process?" Public Choice 39:33-66.

Frankfurter, Felix, and James M. Landis. 1928. The Business of the Supreme Court: A Study in the Federal Judicial System. New York: Macmillan.

Gallagher, John. 2006. "Justice for the Railroads.” Traffic World 27, July 17.

Gilligan, Thomas W., William J. Marshall, and Barry R. Weingast. 1989. "Regulation and the Theory of Legislative Choice." Journal of Law and Economics $32: 35-61$.

Giordano, James. 1997. "Return to Scale and Market Concentration among the Largest Survivors of Deregulation in the US Trucking Industry." Applied Economics 29:101-10.

Grimm, Curtis, and Clifford Winston. 2000. "Competition in the Deregulated Railroad Industry: Sources, Effects, and Policy Issues." In Deregulation of Network Industries: What's Next?, edited by Sam Peltzman and Clifford Winston, 41-72. Washington, DC: AEI-Brookings Joint Center for Regulatory Studies.

Grodinsky, Julius. 1950. The Iowa Pool: A Study in Railroad Competition, 1870-84. Chicago: University of Chicago Press.

Guerin-Calvert, Margaret, and Roger G. Noll. 1991. "Computer Reservation Systems and Their Network Linkages to the Airline Industry." In Electronic Service Networks: A Business and Public Policy Challenge, edited by Margaret E. GuerinCalvert and Steven S. Wildman, 145-87. New York: Praeger.

Hilton, George W. 1966. "The Consistency of the Interstate Commerce Act." Journal of Law and Economics 9:87-114.

Hunter, Natalie J., and Stephen L. Mangum. 1995. "Economic Regulation, Employment Relations, and Accident Rates in the US Motor Carrier Industry." Labor Studies Journal 20:48-63.

Ivaldi, Marc, and Gerard McCullough. 2010. "Welfare Tradeoffs in US Rail Mergers.” TSE Working Paper 10-196, Toulouse School of Economics, Toulouse.

Kolko, Gabriel. 1965. Railroads and Regulation, 1877-1916. Princeton, NJ: Princeton University Press.

Landes, William, and Richard Posner. 1979. “Adjudication as a Private Good.” Journal of Legal Studies 8:235-84.

Loomis, Carol. 1999. "Mr. Buffett on the Stock Market." Fortune, vol. 1, issue 10, November 22, 212-20.

McCubbins, Matthew, Roger Noll, and Barry Weingast. 1989. "Structure and Process, Politics and Policy: Administrative Arrangements and the Political Control of Agencies." Virginia Law Review 75:431-82.

Miller, Amalia R. 2010. "Did the Airline Tariff Publishing Case Reduce Collusion?" Journal of Law and Economics 53:569-86.

Moore, Thomas Gale. 1978. "The Beneficiaries of Trucking Regulation.” Journal of Law and Economics 21:327-43.

Morrison, Steven, and Clifford Winston. 2000. "The Remaining Role for Government Policy in the Deregulated Airline Industry." In Deregulation of Network Industries: What's Next?, edited by Sam Peltzman and Clifford Winston, 1-40. Washington, DC: AEI-Brookings Joint Center for Regulatory Studies.

Mueller, Milton L. 1997. Universal Service: Competition, Interconnection, and Monopoly in the Making of the American Telephone System. Cambridge, MA: MIT Press.

Nebesky, William, B. Starr McMullen, and Man-Keung Lee. 1995. "Testing for Market Power in the US Motor Carrier Industry." Review of Industrial Organization 10:559-76. 
Noll, Roger, and Bruce Owen. 1989. "The Anticompetitive Uses of Regulation: United States v. AT\&T.” In The Antitrust Revolution, first edition, edited by John E. Kwoka and Lawrence J. White, 328-75. New York: Scott, Foresman.

Peltzman, Sam. 1976. "Toward a More General Theory of Regulation." Journal of Law and Economics 19:211-40. 1989. "The Economic Theory of Regulation after a Decade of Deregulation." Brookings Papers on Economic Activity: Microeconomics no. 3, 1-41.

Pindyck, Robert. 2008. "Sunk Costs and Real Options in Antitrust Analysis." In Issues in Competition Law and Policy, edited by W. Collins, 619-40. ABA Monograph.

Pirrong, Stephen Craig. 1992. "An Application of Core Theory to the Analysis of Ocean Shipping Markets." Journal of Law and Economics 35:89-131.

Posner, Richard. 1974. "Theories of Economic Regulation." The Bell Journal of Economics and Management Science 5:335-58.

- 2003. Antitrust Law: An Economic Perspective, second edition. Chicago: University of Chicago Press.

Rabin, Robert L. 1986. "Federal Regulation in Historical Perspective.” Stanford Law Review 38:1189-326.

Ripley, William Z. 1913. Railroads: Rates and Regulation, 2nd ed. New York: Longmans, Green, and Co.

Robinson, Sara. 2004. "Antitrust Lawsuit Over Medical Residency System Is Dismissed." New York Times, August 14.

Rose, Nancy. 1987. "Labor Rent Sharing and Regulation: Evidence from the Trucking Industry." Journal of Political Economy 95:1146-78.

Shepsle, Kenneth, and Mark Bonchek. 1997. Analyzing Politics: Rationality, Behavior, and Institutions. New York: Norton.

Sklar, Martin J. 1988. The Corporate Reconstruction of American Capitalism, 18901917. Cambridge: Cambridge University Press.

Starr, Paul. 2004. The Creation of the Media: Political Origins of Modern Communications. New York: Basic Books.

Stephenson, Matthew. 2005. "Legislative Allocation of Delegated Power: Uncertainty, Risk, and the Choice between Agencies and Courts." Harvard Law and Economics Discussion Paper No. 506.

Stigler, George. 1971. "The Theory of Economic Regulation." The Bell Journal of Economics and Management Science 2:3-21.

US Department of Transportation. Various years. T1 US Air Carrier Traffic Statistics.

Vellturo, Christoper, Ernst Berndt, Ann Friedlander, Judy Chiang, and Mark Showalter. 1992. "Deregulation, Mergers and Cost Savings in Class I U.S. Railroads, 1974-1986." Journal of Economics and Management Strategy 1:339-69.

Weiman, David F., and Richard C. Levin. 1994. "Preying for Monopoly? The Case of Southern Bell Telephone Company, 1894-1912." Journal of Political Economy 102:103-26. 